\title{
The Nursing Care Given for Immigrant Women with Language Barrier in Clinics of Gynecology and Obstetrics of Turkey
}

\author{
Hande Dag* \\ Department Obstetric and Gynecologic Nursing, Dokuz Eylul University, Turkey
}

Submission: May 28, 2017; Published: June 05, 2017

*Corresponding author: Hande Dag, Department Obstetric and Gynecologic Nursing, Dokuz Eylul University, Turkey, Email: hande.yagcan@gmail.com

\section{Opinion}

As being a lecturer in a University, Faculty of Nursing, in Obstetric and Gynaecologic Nursing Department, whole year I am making nursing practice with our students in a State Hospital of Izmir where is the third largest city of Turkey. This hospital is the one of the most crowded and specialized in obstetric and gynecology. Generally this hospital care the women who have low income and status, also the immigrants are one of this women. We met many Syrian and illegal immigrant women in delivery and postpartum care units. Because of their language barrier, women and the health staff couldn't understand each others. The ministry of Health also give only one translator to The Hospital, but in our practice process we couldn't see the translator either. Also there are any Arabic patient education brochures (antenatal, delivery-operation preparations, postpartum mother and baby care) information sheets (warning or redirection signs). Due to this language barrier, health staff couldn't give them information about their care, use bad communication skills and show unacceptable behaviours and it sometimes causes mutual violence with the patients and their relatives. Also the health staff couldn't manage care of these patients since 2012 and have burnout syndrome which make nursing care not humanistic and holistic.

I would like to share a case which I and my male nursing student experienced during our practice in the postnatal clinics of the hospital and shows general care problems of the migrants. SO is 21-year old and have emigrated from Syria, couldn't speak Turkish and had a caesarean section and at 1st postpartum day. While we began to care her, we realized that she didn't has her baby and was very anxious because she didn't have knowledge about status of the baby. Then, we tried to ask the mother where her baby was, however as we didn't manage to communicate, we tried to get information from the head nurse but she didn't know intensive care unit of which hospital the newborn had been referred and the reason either. It was necessary to teach the mother how to milk, as breastfeeding of the newborn or milking within initial 30 minutes is required in order to provide stimulation of milk passage and mother-baby attachment during postpartum period. Additionally, for the mother to secrete the hormone oxytocin which is required for milk passage, she must have been relaxed. Although it was only one day ago when the birth occurred, this training hadn't been provided by the nurses of the clinic, and engorgement began to develop in breasts of the mother and pain started in breasts. In order to obtain breast milk which is necessary for immune system of the newborn and to prevent the mother to have mastitis training concerning milking, family planning methods and postpartum mother and care was provided by trying to communicate by using patients who knew Arabic, their companions and Google Translate Programs. However, the things that she would like to ask and other her complaints concerning the training couldn't be learned. When the mother was visited at second day, other patients reported that she milked her breasts throughout the whole night, however it was determined that because of the language barrier in communication and wrong translation of the companions, she removed all milk out of the fridge, continuously milked into the same milk storage packs and sterility of the milk was lost due to this misunderstanding. When the mother was told that she wouldn't be able to give this to her baby, she felt so sad.

Interventions like vital signs were tried to be applied by using body language. However, failure in informing the patient about the procedures before bleeding monitoring, lactation and involution control, and her hesitation about application of this procedure by a male nurse due to cultural differences led to the patient to experience anxiety and to not performing of the interventions appropriately. 


\section{Conclusion}

We confront language barrier in communication as an enormous problem in performing of nursing interventions and providing of necessary training that mothers need in foreign patients who are Syrian or don't know the language. Also one more time we recognized that the intercultural nursing lessons are very important and have to give nursing students in their undergraduate programs.

In addition to all, Turkey received nearly 3 million of immigrant women had been given birth more than 180.000 in five years which is very coherent with fertility and post migration theory. Ministry of Health and hospital administration are required to provide supports such as interpreter support

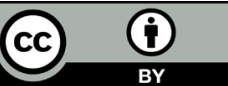

This work is licensed under Creative Commons Attribution 4.0 License and informative brochures in Arabic etc., which may contribute to solution of this communication problem and for patients to receive better nursing care.

The news which are about the opportunities provided by our country to refugees are included the resident permits, university admission without an exam, educational courses organized by Ministry of Education, wheelchairs for disabled refugees, salary, container city for housing needs, playgrounds for children and trips to the surroundings as a social activity which are seems sufficient for the immigrants. But unfortunately, the problems of the refugees in Turkey which are health problems due to drinking water, nutrition and bad weather conditions, language barrier in health care system, inadequate educational conditions for age groups, and prostitution of refugee women are still continue.

\section{Your next submission with Juniper Publishers will reach you the below assets}

- Quality Editorial service

- Swift Peer Review

- Reprints availability

- E-prints Service

- Manuscript Podcast for convenient understanding

- Global attainment for your research

- Manuscript accessibility in different formats

( Pdf, E-pub, Full Text, Audio)

- Unceasing customer service

Track the below URL for one-step submission https://juniperpublishers.com/online-submission.php 